\title{
6. LITHOLOGY AND CLAY MINERALOGY OF SEDIMENTS FROM HOLE 346
}

\author{
M.A. Rateev, N.V. Renngarten, V.D. Shutov, and V.A. Drits, \\ Geological Institute of the Academy of Sciences, USSR
}

\section{INTRODUCTION}

The sediments from Site 346 have the following ages: Pliocene to Pleistocene $(0-25.5 \mathrm{~m})$, middle Miocene $(25.5-101.5 \mathrm{~m})$, Oligocene (101.5 [?] to $120.5 \mathrm{~m})$, and Eocene $(120.5$ [?] to $187 \mathrm{~m})$. On the basis of a large number of lithologic mineralogic characteristics, four major series are distinguished in the cored interval (Figure 1); for each series, more detailed subdivisions (subseries) are distinguished (Figure 1). ${ }^{1}$

\section{DESCRIPTIONS OF THE SERIES AND SUBSERIES}

\section{Series 1 (0-31.5 m) (Samples 2000-2018)}

The sediments of this series are easily distinguished from those of the underlying series. This was largely because of the unique sedimentation environment in the basin that prevailed during the time of deposition. This was a time of continental glaciation of the northern hemisphere, which led to ice transport of terrigenous material to the oceanic environment.

Series 1 contains a typical hydromica association with chlorite and montmorillonite. Aluminum dioctahedral hydromicas (illites) dominate in the association (60\%-70\%), with trioctahedral chlorites (to $20 \%$ $30 \%$ ), montmorillonite (to $20 \%$ ), and kaolinite $(10 \%$ $20 \%) \times($ Table 1$)$. The series has a total thickness of 31.5 meters and is divided into two subseries.

\section{Subseries 1-1 (0-10.5 m; Samples 2000-2007)}

This subseries is characterized by an abundance of foraminiferal tests, well preserved, and probably planktonic. Clay sediments, variously silty, prevail in the section, often with an admixture of sand-size quartz grains, and fragments of basalts and other rocks, including acid and basic volcanic glasses.

\section{Subseries 1-2 (10.5-31.5 m; Samples 2007-2017; 21 m thick)}

The subseries is composed of unsorted sand-clay-silt polymictic sediments. Usually they have the following characteristics: a pelitomorphous, fine clay matrix, variously enriched in silty components, nonuniformly distributed fragments of different sizes (from sand to gravel and pebbles) consisting of various rock types; quartz, feldspar grains, and plates of micas and chlorite.

'The "series or subseries" do not necessarily correspond to "units or subunits" as defined by shipboard sedimentologists (see Site Report chapter, this volume). Also sediment terminology is that of the authors and may not correspond to shipboard designations. Sample numbers are those assigned by the authors for the investigations.

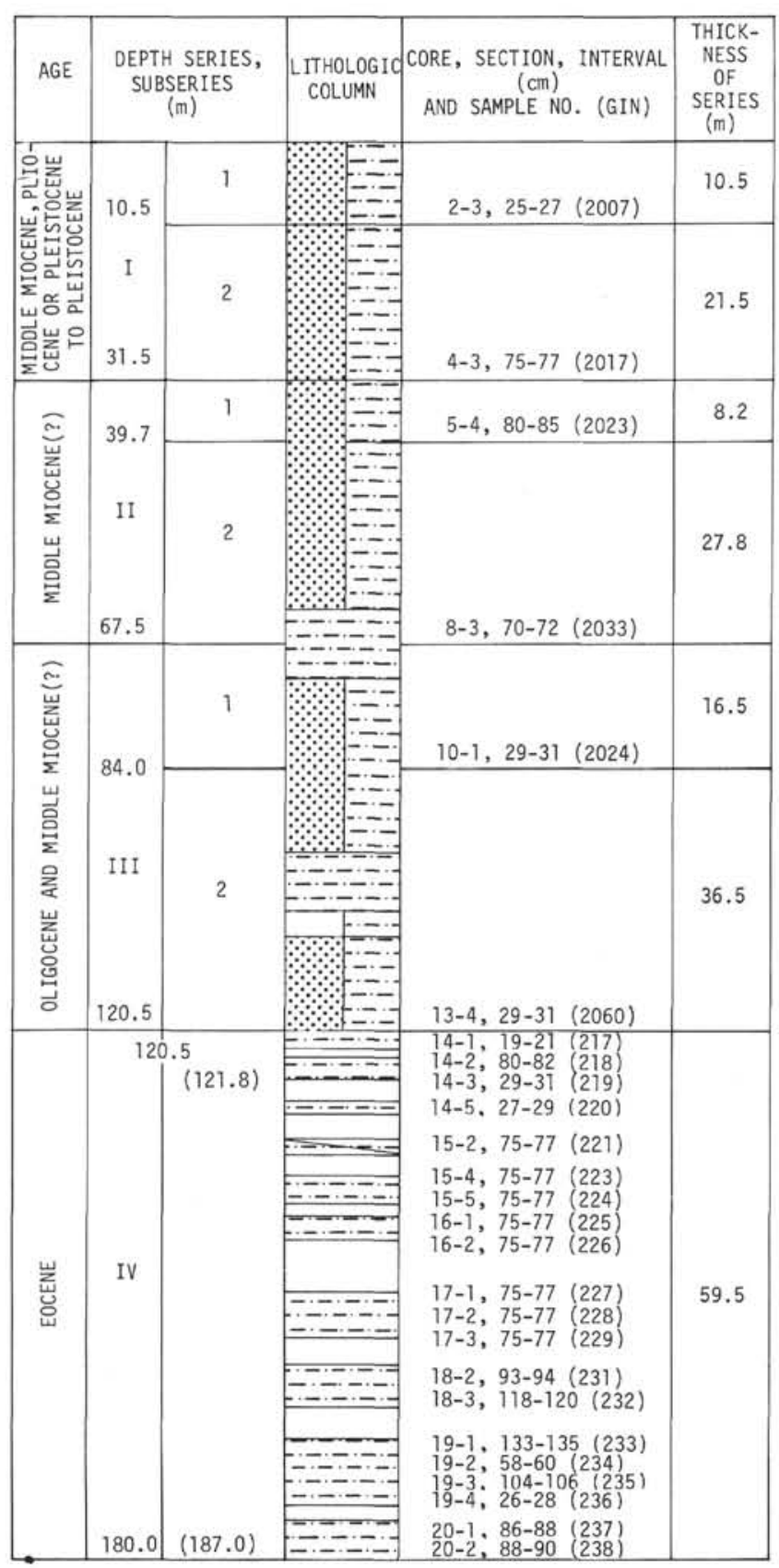

Figure 1. Stratigraphic section and sample numbers, Site 346.

Apart from fragments of basalt, quartzites and claystones, fragments of hornblende biotite schists, granites, and limestones are also present. The 
TABLE 1

X-Ray Analysis Data of Clay and Other Minerals, Site 346

\begin{tabular}{|c|c|c|c|c|c|c|c|c|c|c|c|c|c|c|}
\hline \multirow[b]{2}{*}{ Age } & \multirow[b]{2}{*}{$\begin{array}{l}\text { Depth } \\
(\mathrm{m})\end{array}$} & \multicolumn{2}{|c|}{ Sample Numbers } & \multirow[b]{2}{*}{$\begin{array}{c}\text { Size of } \\
\text { Fraction }\end{array}$} & \multirow[b]{2}{*}{ Glauconites } & \multirow[b]{2}{*}{ Montmorillonite } & \multirow[b]{2}{*}{ Hydromica } & \multirow{2}{*}{ Chlorite } & \multirow[b]{2}{*}{ Kaolinite } & \multirow{2}{*}{$\begin{array}{l}\text { Mixed- } \\
\text { Layered } \\
\text { Minerals }^{\mathrm{a}}\end{array}$} & \multirow[b]{2}{*}{$\begin{array}{c}\text { Other } \\
\text { Minerals }\end{array}$} & \multirow[b]{2}{*}{ Series } & \multirow[b]{2}{*}{ Subseries } & \multirow{2}{*}{$\begin{array}{l}\text { Associations } \\
\text { of Clay and } \\
\text { Authigenic } \\
\text { Minerals }\end{array}$} \\
\hline & & $\begin{array}{c}\text { Sample } \\
\text { (Interval in } \mathrm{cm} \text { ) }\end{array}$ & $\begin{array}{l}\text { GIN } \\
\text { USSR }\end{array}$ & & & & & & & & & & & \\
\hline & & $1-2,75-77$ & 2001 & $<1 \mu \mathrm{m}$ & & $\begin{array}{l}\text { Ca-montmorillonite } \\
\text { up to } 20 \%\end{array}$ & $\begin{array}{l}\text { Illite diocta- } \\
\text { hedral with- } \\
\text { out labile } \\
\text { beds up to } \\
60-70 \% \\
\text { Modifications } \\
\text { 1 Md and 1 M }\end{array}$ & $\begin{array}{l}\text { Trioctahedral } \\
20 \% \text {, perfectly } \\
\text { related struc- } \\
\text { turally with } \\
\text { biotite }\end{array}$ & $\begin{array}{l}\text { Little up } \\
\text { to } 10-15 \%\end{array}$ & & & & & \\
\hline & & $1-3,75-77$ & 2002 & $<1 \mu \mathrm{m}$ & & $\begin{array}{l}\mathrm{Ca}, \text { Na-montmoril- } \\
\text { lonite } 10 \%\end{array}$ & Illite $\sim 60 \%$ & $\begin{array}{l}\text { Trioctahedral } \\
20 \% \text {, perfectly } \\
\text { related struc- } \\
\text { turally with } \\
\text { biotite }\end{array}$ & $\begin{array}{l}\text { Little up } \\
\text { to } 10-15 \%\end{array}$ & $(1-M)$ & & & & \\
\hline & & $14,34-36$ & $2003^{a}$ & $<1 \mu \mathrm{m}$ & & $\begin{array}{l}\mathrm{Ca}, \mathrm{Na}-\mathrm{montmoril-} \\
\text { lonite } 15-30 \%\end{array}$ & Illite $40-60 \%$ & $\begin{array}{l}\text { Trioctahedral } \\
20 \% \text {, perfectly } \\
\text { related struc- } \\
\text { turally with } \\
\text { biotite }\end{array}$ & $\begin{array}{l}\text { Up to } 15- \\
20 \%\end{array}$ & - & & & & \\
\hline & & 14 & 2003 & $<1 \mu \mathrm{m}$ & & $\begin{array}{l}\mathrm{Ca}, \mathrm{Na}-\mathrm{montmoril} \\
\text { lonite } 15-30 \%\end{array}$ & Illite $40-60 \%$ & $\begin{array}{l}\text { Trioctahedral } \\
20 \% \text {, perfectly } \\
\text { related struc- } \\
\text { turally with } \\
\text { biotite }\end{array}$ & $\begin{array}{l}\text { Up to } 15 \text { - } \\
20 \%\end{array}$ & (V-Ch) & & & & \\
\hline & & $1-5,75-77$ & 2004 & $<1 \mu \mathrm{m}$ & & $\begin{array}{l}\mathrm{Ca}, \text { Na-montmoril- } \\
\text { lonite } 15-30 \%\end{array}$ & Illite $40-60 \%$ & $\begin{array}{l}\text { Trioctahedral } \\
20 \% \text {, perfectly } \\
\text { related struc- } \\
\text { turally with } \\
\text { biotite }\end{array}$ & $\begin{array}{l}\text { Up to } 15- \\
20 \%\end{array}$ & - & & & & \\
\hline & & $2-1,75-77$ & 2005 & $<1 \mu \mathrm{m}$ & & $\begin{array}{l}\text { Ca, Na-montmoril- } \\
\text { lonite } 15-30 \%\end{array}$ & Illite $40-60 \%$ & $\begin{array}{l}\text { Trioctahedral } \\
20 \% \text {, perfectly } \\
\text { related struc- } \\
\text { turally with } \\
\text { biotite }\end{array}$ & $\begin{array}{l}\text { Up to } 15- \\
20 \%\end{array}$ & $(\mathrm{~V}-\mathrm{Ch})$ & & & & \\
\hline 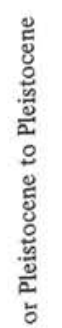 & & $2-2,75-77$ & $2007^{\mathrm{a}}$ & $<1 \mu \mathrm{m}$ & & $\begin{array}{l}\text { Ca, Na-montmoril- } \\
\text { lonite } 15-30 \%\end{array}$ & Illite $40-60 \%$ & $\begin{array}{l}\text { Trioctahedral } \\
20 \% \text {, perfectly } \\
\text { related struc- } \\
\text { turally with } \\
\text { biotite } \\
\text { Trioctahedral } \\
20 \% \text {, perfectly } \\
\text { related struc- } \\
\text { turally with } \\
\text { biotite }\end{array}$ & $\begin{array}{l}\text { Up to } 15 \text { - } \\
20 \%\end{array}$ & - & & 1 & & $\begin{array}{l}\text { Hydromicaceous } \\
\text { with chlorite and } \\
\text { montmorillonite } \\
\text { (intermediate } \\
\text { products of trans- } \\
\text { formation of } \\
\text { biotite) }\end{array}$ \\
\hline
\end{tabular}




\begin{tabular}{|c|c|c|c|c|c|c|c|c|c|}
\hline & $2-4,75-77$ & 2008 & $<1 \mu \mathrm{m}$ & $\begin{array}{l}\mathrm{Ca}, \mathrm{Na} \text {-montmoril- } \\
\text { lonite } 15-30 \%\end{array}$ & Illite $40-60 \%$ & $\begin{array}{l}\text { Trioctahedral } \\
20 \% \text {, perfectly } \\
\text { related struc- } \\
\text { turally with } \\
\text { biotite } \\
\text { Trioctahedral } \\
20 \% \text {, perfectly } \\
\text { related struc- } \\
\text { turally with } \\
\text { biotite }\end{array}$ & $\begin{array}{l}\text { Up to } 15- \\
20 \%\end{array}$ & $(\mathrm{I}-\mathrm{M})$ & \\
\hline & $3-1,75-77$ & 2009 & $<1 \mu \mathrm{m}$ & $\begin{array}{l}\mathrm{Ca}, \mathrm{Na}-\text { montmoril- } \\
\text { lonite } 15-30 \%\end{array}$ & Illite $40-60 \%$ & $\begin{array}{l}\text { Trioctahedral } \\
20 \% \text {, perfectly } \\
\text { related struc- } \\
\text { turally with } \\
\text { biotite }\end{array}$ & $\begin{array}{l}\text { Up to } 15- \\
20 \%\end{array}$ & & \\
\hline & $3-2,75-77$ & 2010 & $<1 \mu \mathrm{m}$ & $\mathrm{Ca}, \mathrm{Na}$-montmoril- & Illite $40-60 \%$ & $\begin{array}{l}\text { Trioctahedral } \\
20 \% \text {, perfectly } \\
\text { related struc- } \\
\text { turally with } \\
\text { biotite }\end{array}$ & $\begin{array}{l}\text { Up to } 15- \\
20 \%\end{array}$ & & \\
\hline & $3-3,96-98$ & 2011 & $<1 \mu \mathrm{m}$ & $\begin{array}{l}\mathrm{Ca}, \text { Na-montmoril- } \\
\text { lonite } 15-30 \%\end{array}$ & Illite $\sim 50 \%$ & $\begin{array}{l}\text { Trioctahedral } \\
20 \% \text {, perfectly } \\
\text { related struc- } \\
\text { turally with } \\
\text { biotite }\end{array}$ & - & & \\
\hline & $3-4,75-77$ & 2012 & $<1 \mu \mathrm{m}$ & $\begin{array}{l}\text { Ca-montmorillonite } \\
\sim 20 \%\end{array}$ & $\begin{array}{l}\text { Illite from } \\
50-60 \%\end{array}$ & $\begin{array}{l}\text { Trioctahedral } \\
20 \% \text {, perfectly } \\
\text { related struc- } \\
\text { turally with } \\
\text { biotite }\end{array}$ & $15-20 \%$ & (V-Ch) & \\
\hline & $3-5,75-77$ & 2013 & $<1 \mu \mathrm{m}$ & $\begin{array}{l}\text { Ca-montmorillonite } \\
\sim 20 \%\end{array}$ & $\begin{array}{l}\text { Illite from } \\
50-60 \%\end{array}$ & $\begin{array}{l}\text { Trioctahedral } \\
20 \% \text {, perfectly } \\
\text { related struc- } \\
\text { turally with } \\
\text { biotite }\end{array}$ & $15-20 \%$ & - & \\
\hline & $3-6,75-77$ & 2014 & $<1 \mu \mathrm{m}$ & - & Illite $\sim 50 \%$ & $\begin{array}{l}\text { Trioctahedral } \\
\text { variety of } \\
\text { good crystal, } \\
\text { up to } 20 \%\end{array}$ & - & & \\
\hline & $4-1,75-77$ & 2015 & $<10 \mu \mathrm{m}$ & - & Illite $\sim 50 \%$ & $\begin{array}{l}\text { Trioctahedral } \\
\text { variety of } \\
\text { good crystal } \\
\text { up to } 20 \%\end{array}$ & - & & $\begin{array}{l}\text { Quartz } \\
\text { feldspar }\end{array}$ \\
\hline & $4-3,75-77$ & 2017 & $<10 \mu \mathrm{m}$ & $\begin{array}{l}\text { Montmorillonite up } \\
\text { to } 20 \%\end{array}$ & Illite $\sim 50 \%$ & $\begin{array}{l}\text { Trioctahedral } \\
\text { variety of } \\
\text { good crystal } \\
\text { up to } 20 \%\end{array}$ & - & & $\begin{array}{l}\text { Quartz } \\
\text { feldspar }\end{array}$ \\
\hline 31.5 & $4-4,75-77$ & 2018 & $<1 \mu \mathrm{m}$ & $\begin{array}{l}\text { Montmorillonite up } \\
\text { to } 20 \%\end{array}$ & Illite $\sim 50 \%$ & $5-10 \%$ & $\begin{array}{l}\text { Up to } \\
15 \%\end{array}$ & (V-Ch) & \\
\hline
\end{tabular}


TABLE 1 - Continued

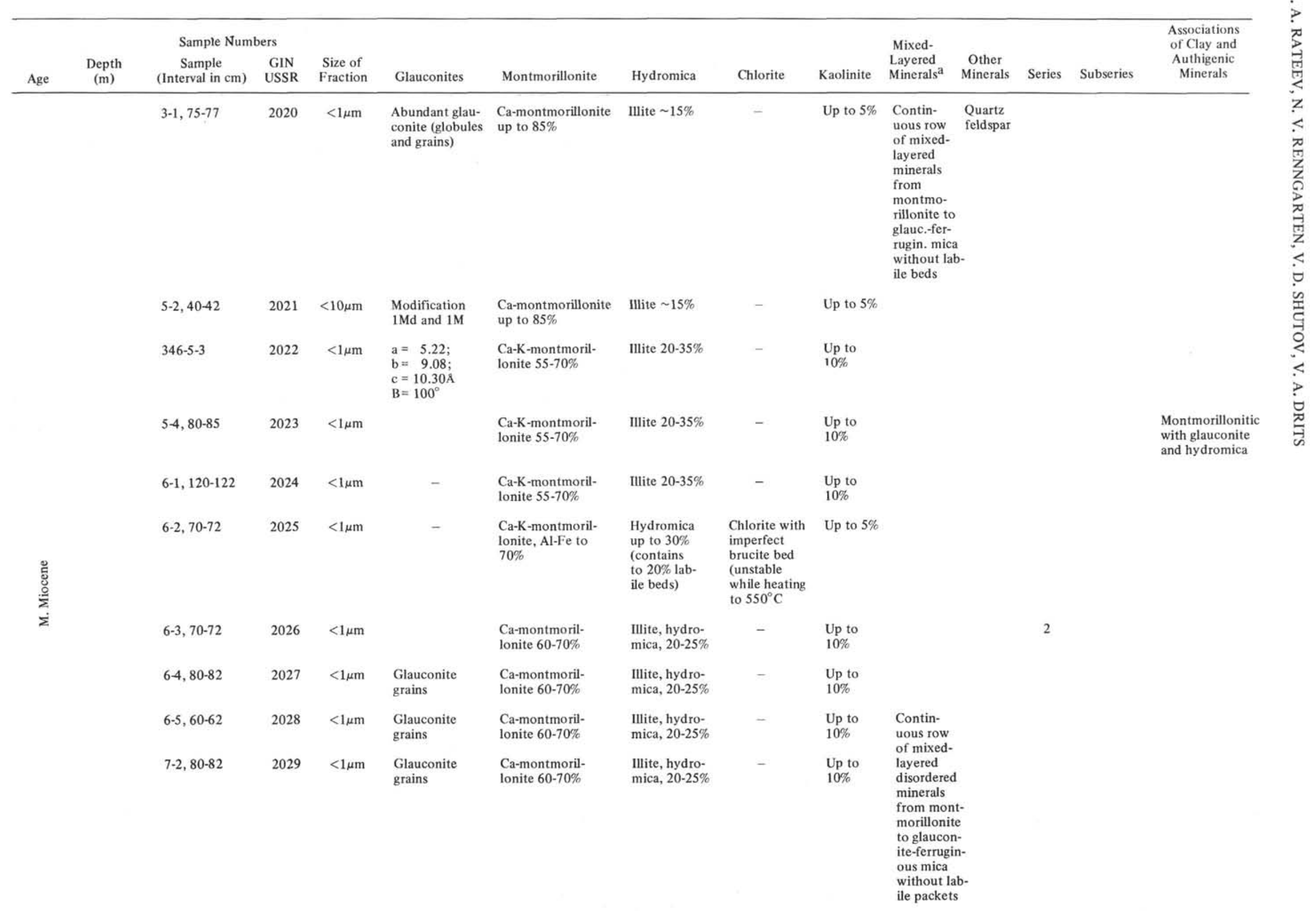




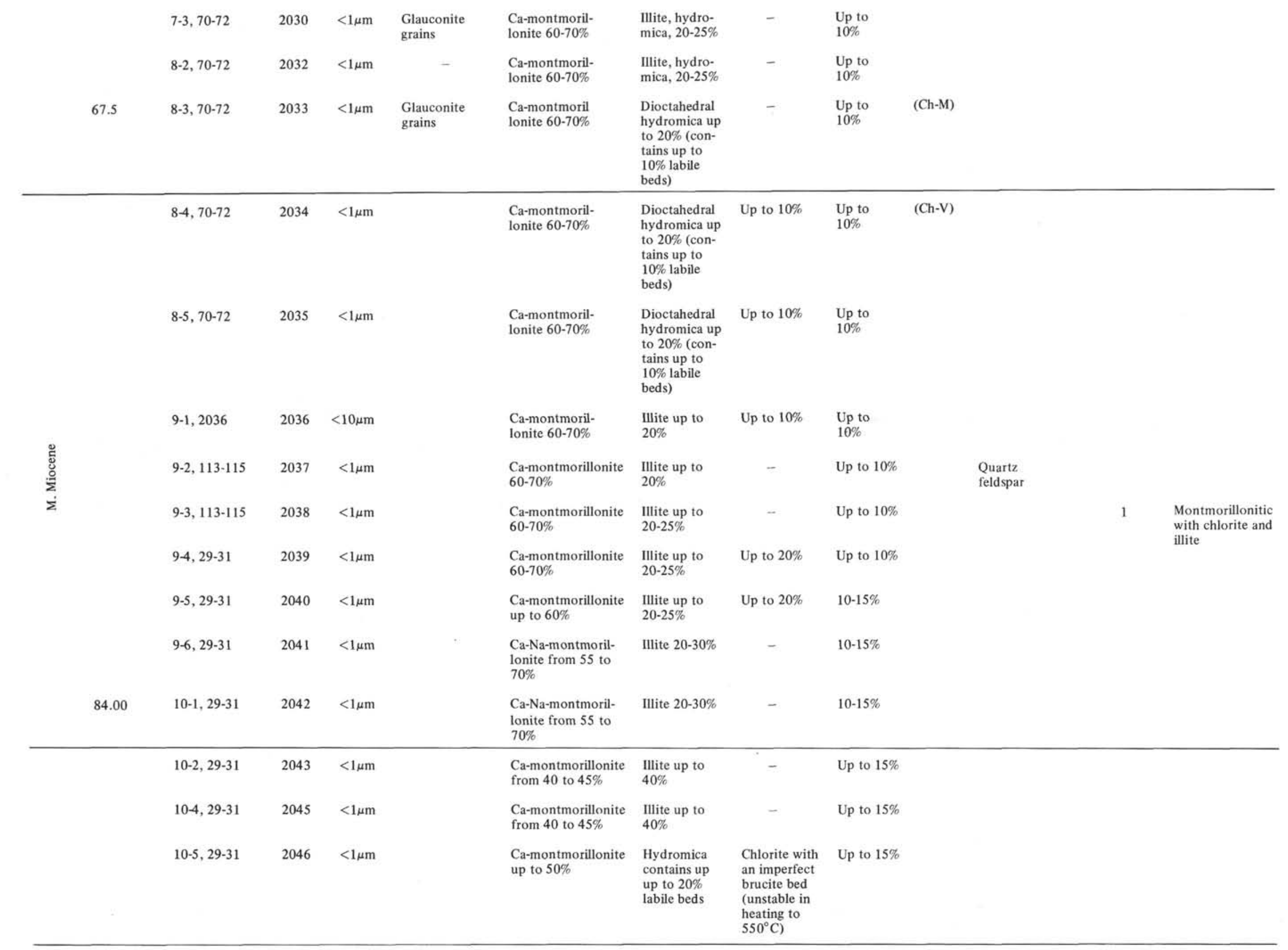




\begin{tabular}{|c|c|c|c|c|c|c|c|c|c|c|c|c|c|c|}
\hline Age & $\begin{array}{l}\text { Depth } \\
(\mathrm{m})\end{array}$ & $\begin{array}{l}\text { Sample Numb } \\
\text { Sample } \\
\text { (Interval in } \mathrm{cm} \text { ) }\end{array}$ & $\begin{array}{l}\text { ers } \\
\text { GIN } \\
\text { USSR }\end{array}$ & $\begin{array}{l}\text { Size of } \\
\text { Fraction }\end{array}$ & Glauconites & Montmorillonite & Hydromica & Chlorite & Kaolinite & $\begin{array}{l}\text { Mixed- } \\
\text { Layered } \\
\text { Minerals }^{\mathrm{a}}\end{array}$ & $\begin{array}{l}\text { Other } \\
\text { Minerals }\end{array}$ & Series & Subseries & $\begin{array}{l}\text { Associations } \\
\text { of Clay and } \\
\text { Authigenic } \\
\text { Minerals }\end{array}$ \\
\hline \multirow{14}{*}{ 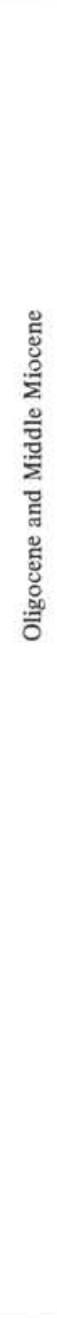 } & & $10-6,29-31$ & 2047 & $<1 \mu \mathrm{m}$ & & $\begin{array}{l}\text { Ca-montmorillonite } \\
\text { about } 40 \%\end{array}$ & Illite $30-40 \%$ & Traces & $15-20 \%$ & & & 3 & 2 & \multirow{14}{*}{$\begin{array}{l}\text { Montmorillonitic } \\
\text { with hydromica } \\
\text { (and illite) }\end{array}$} \\
\hline & & $11-1,129-131$ & 2048 & $<1 \mu \mathrm{m}$ & & $\begin{array}{l}\text { Ca-montmorillonite } \\
\text { about } 40 \%\end{array}$ & Illite $30-40 \%$ & Traces & $15-20 \%$ & & & & & \\
\hline & & $11-2,59-61$ & 2049 & $<1 \mu \mathrm{m}$ & & $\begin{array}{l}\text { Ca-montmorillonite } \\
\text { about } 40 \%\end{array}$ & Illite $30-40 \%$ & - & $15-20 \%$ & & & & & \\
\hline & & $11-3,29-31$ & 2050 & $<1 \mu \mathrm{m}$ & & $\begin{array}{l}\text { Ca-montmorillonite } \\
\text { about } 40 \%\end{array}$ & Illite $30-40 \%$ & Traces & Traces & & Feldspar & & & \\
\hline & & $11-4,29-31$ & 2051 & $<1 \mu \mathrm{m}$ & & $\begin{array}{l}\text { Ca-montmorillonite } \\
\text { about } 40 \%\end{array}$ & Illite $30-40 \%$ & Traces & Traces & & & & & \\
\hline & & $12-1,99-101$ & 2052 & $<1 \mu \mathrm{m}$ & & $\begin{array}{l}\text { Ca-montmorillonite } \\
\text { about } 40 \%\end{array}$ & Illite $30-40 \%$ & Traces & Traces & & & & & \\
\hline & & $12-2,29-31$ & 2053 & $<1 \mu \mathrm{m}$ & & $\begin{array}{l}\text { Ca-montmorillonite } \\
\text { about } 40 \%\end{array}$ & Illite $30-40 \%$ & Traces & Traces & & & & & \\
\hline & & $12-3,29-31$ & 2054 & $<1 \mu \mathrm{m}$ & & $\begin{array}{l}\text { Ca-Na-montmoril- } \\
\text { lonite aluminic } \\
\text { ferruginous }\end{array}$ & $\begin{array}{l}\text { Hydromica to } \\
30 \% \text { (contains } \\
\text { up to } 10 \% \text { lab- } \\
\text { ile beds) }\end{array}$ & Up to $5 \%$ & - & $\begin{array}{l}\text { (I-M) up } \\
80 \% \text { labile } \\
\text { packets } \\
\text { disordered } \\
\text { alteration }\end{array}$ & & & & \\
\hline & & $12-4,29-31$ & 2055 & $<1 \mu \mathrm{m}$ & & $\begin{array}{l}\text { Ca-Na-montmoril- } \\
\text { lonite } 40-50 \%\end{array}$ & $\begin{array}{l}\text { Illite up to } \\
30 \%\end{array}$ & Up to $5 \%$ & $10-15 \%$ & & & & & \\
\hline & & $12-5,29-31$ & 2056 & $<1 \mu \mathrm{m}$ & & $\begin{array}{l}\text { Ca-Na-montmoril- } \\
\text { lonite } 40-50 \%\end{array}$ & $\begin{array}{l}\text { Illite up to } \\
30 \%\end{array}$ & Up to $5 \%$ & $10-15 \%$ & & & & & \\
\hline & & $13-1,29-31$ & 2057 & $<1 \mu \mathrm{m}$ & & $\begin{array}{l}\text { Ca-Na-montmoril- } \\
\text { lonite } 40-50 \%\end{array}$ & $\begin{array}{l}\text { Illite up to } \\
30 \%\end{array}$ & Up to $5 \%$ & $10-15 \%$ & $\begin{array}{l}\text { (1-M) dis- } \\
\text { ordered }\end{array}$ & & & & \\
\hline & & $13-2,29-31$ & 2058 & $<1 \mu \mathrm{m}$ & & $\begin{array}{l}\text { Ca-Na-montmoril- } \\
\text { lonite } 40-50 \%\end{array}$ & $\begin{array}{l}\text { Illite up to } \\
30 \%\end{array}$ & Up to $5 \%$ & $10-15 \%$ & & & & & \\
\hline & & $13-3,29-31$ & 2059 & $<1 \mu \mathrm{m}$ & & $\begin{array}{l}\mathrm{Na}-\mathrm{Ca} \text {-montmoril- } \\
\text { lonite, } 50-60 \%\end{array}$ & $\begin{array}{l}\text { Hydromica } \\
20-30 \% \text { (con- } \\
\text { tains up to } \\
20 \% \text { labile } \\
\text { beds) }\end{array}$ & Up to $5 \%$ & Up to $10 \%$ & (I-M) little & Feldspar & & & \\
\hline & \multirow[t]{2}{*}{120.5} & $13-4,29-31$ & 2060 & $<1 \mu \mathrm{m}$ & & $\begin{array}{l}\text { Na-Ca-montmoril- } \\
\text { lonite up to } 70 \%\end{array}$ & $\begin{array}{l}\text { Illite up to } \\
25 \%\end{array}$ & - & Up to $10 \%$ & (I-M) little & & & & \\
\hline & & $14-5,27-29$ & 220 & $<10 \mu \mathrm{m}$ & & $\begin{array}{l}\text { Montmorillonite } \\
\text { dioctahedral Al- } \\
\text { Fe, } 20 \%\end{array}$ & $\begin{array}{l}\text { Up to } 20 \% \\
\text { labile pack- } \\
\text { ets } 40-50 \%\end{array}$ & $\begin{array}{l}\text { Ferruginous, } \\
\text { a little im- } \\
\text { perfect (un- } \\
\text { stable in ig- } \\
\text { nition); 20- } \\
25 \%\end{array}$ & $10-15 \%$ & - & $\begin{array}{l}\text { Quartz } \\
\text { feldspar }\end{array}$ & & & $\begin{array}{l}\text { Terrigenous } \\
\text { polycompo- } \\
\text { nent montmo- } \\
\text { rillonite-vermi- } \\
\text { culite, hydro- } \\
\text { micaceous }\end{array}$ \\
\hline
\end{tabular}




\begin{tabular}{|c|c|c|c|c|c|c|c|c|c|c|c|}
\hline $136.5-138.0$ & $15-5,75-77$ & 224 & $<10 \mu \mathrm{m}$ & $\begin{array}{l}\text { Montmorillonite } \\
\text { with abnormally } \\
\text { high content of } \\
\text { adsorbed } \mathrm{SiO}_{2} \\
\text { d } \sim 19 \AA \text {; mixed- } \\
\text { layered phase } \\
\text { possible; } \mathrm{Al}-\mathrm{Fe} \text {, } \\
10-15 \%\end{array}$ & $\begin{array}{l}\text { Illitic type } \\
30-40 \%\end{array}$ & $\begin{array}{l}\text { Chlorite fer- } \\
\text { ruginous, } \\
\text { imperfect, } \\
20 \%\end{array}$ & $20 \%$ & - & $\begin{array}{l}\text { Quartz } \\
\text { feldspar }\end{array}$ & & $\begin{array}{l}\text { (products of } \\
\text { biotite trans- } \\
\text { formation) }\end{array}$ \\
\hline $139.5-141.0$ & $16-1,75-77$ & 225 & $<10 \mu \mathrm{m}$ & $\begin{array}{l}\text { Montmorillonite } \\
\text { Al-Fe, contains } \\
\text { packets partly } \\
\text { labile up to } 14 \AA, \\
\text { and up to } 17 \AA ; 30 \%\end{array}$ & $\begin{array}{l}\text { Up to } 20 \% \text { lab- } \\
\text { ile packets } \\
50 \%\end{array}$ & $\begin{array}{l}\text { Chlorite fer- } \\
\text { rugin., im- } \\
\text { perfect, 20\% }\end{array}$ & $20 \%$ & - & $\begin{array}{l}\text { Quartz } \\
\text { feldspar }\end{array}$ & & \\
\hline $149.0-150.5$ & $17-1,75-77$ & 227 & $<10 \mu \mathrm{m}$ & $\begin{array}{l}\text { Montmorillonite } \\
\text { is a product of } \\
\text { biotite decompo- } \\
\text { sition; inherits } \\
\text { mixed-layered } \\
\text { phases from vermi- } \\
\text { culite to montmo- } \\
\text { rillonite } 10-15 \%\end{array}$ & $\begin{array}{l}\text { Illitic type } \\
50-60 \%\end{array}$ & $\begin{array}{l}\text { Chlorite fer- } \\
\text { ruginous }\end{array}$ & Up to $10 \%$ & - & $\begin{array}{l}\text { Quartz } \\
\text { feldspar }\end{array}$ & & \\
\hline $160.0-161.5$ & $18-2,93-94$ & 231 & $<10 \mu \mathrm{m}$ & $\begin{array}{l}\text { Montmorillonite } \\
\text { a product of bio- } \\
\text { tite decomposi- } \\
\text { tion, } 20-30 \%\end{array}$ & $\begin{array}{l}\text { Illitic type } \\
40 \%\end{array}$ & $\begin{array}{l}\text { Chlorite fer- } \\
\text { ruginous, im- } \\
\text { perfect, } 30 \%\end{array}$ & Up to $10 \%$ & - & $\begin{array}{l}\text { Quartz } \\
\text { feldspar }\end{array}$ & 4 & \\
\hline $161.5-163.0$ & $18-3,118-120$ & 232 & $<10 \mu \mathrm{m}$ & $\begin{array}{l}\text { Montmorillonite, } \\
\text { a product of decom- } \\
\text { position of biotite, } \\
20-30 \%\end{array}$ & $\begin{array}{l}\text { Illitic type } \\
40 \%\end{array}$ & $\begin{array}{l}\text { Chlorite fer- } \\
\text { ruginous, im- } \\
\text { perfect, } 30 \%\end{array}$ & Up to $10 \%$ & - & $\begin{array}{l}\text { Quartz } \\
\text { feldspar }\end{array}$ & & \\
\hline $169.5-171.0$ & $19-2,58-60$ & 234 & $<10 \mu \mathrm{m}$ & $\begin{array}{l}\text { A striking example } \\
\text { of montmorillonite } \\
\text { formation through } \\
\text { biotite; a spectrum } \\
\text { of alteration of } \\
\text { packets with dif- } \\
\text { ferent ratio of lab- } \\
\text { ile phase; On dif- } \\
\text { fractogram a wide } \\
\text { plateau with from } \\
10 \text { to } 14 \AA \text { in natu- } \\
\text { ral, and from } 14 \text { to } \\
17 \AA \text { in glycerine } \\
\text { saturated sample; } \\
30 \%\end{array}$ & $\begin{array}{l}\text { With imperfect } \\
\text { chlorite pack- } \\
\text { ets; peak with } \\
\text { well-pro- } \\
\text { nounced asym- } \\
\text { etry towards } \\
\text { small angles; } \\
60 \%\end{array}$ & $\begin{array}{l}\text { Chlorite fer- } \\
\text { ruginous, im- } \\
\text { perfect, } 10 \%\end{array}$ & Up to $10 \%$ & - & $\begin{array}{l}\text { Quartz } \\
\text { feldspar }\end{array}$ & & \\
\hline $172.5-174.0$ & $19-4,26-28$ & 236 & $<10 \mu \mathrm{m}$ & $\begin{array}{l}\text { Montmorillonite } \\
\text { a product of bio- } \\
\text { tite decomposition, } \\
\text { inherits a series of } \\
\text { its transformations } \\
\text { in a series of mixed- } \\
\text { layered minerals, } \\
\text { vermiculite-mont- } \\
\text { morillonite, } 30 \%\end{array}$ & $\begin{array}{l}\text { Illitic type } \\
\text { with relics of } \\
\text { chlorite pack- } \\
\text { ets, } 50 \%\end{array}$ & $\begin{array}{l}\text { Chlorite fer- } \\
\text { ruginous } 10 \%\end{array}$ & Up to $10 \%$ & - & $\begin{array}{l}\text { Quartz } \\
\text { feldspar }\end{array}$ & & \\
\hline
\end{tabular}
${ }_{1}$-I-micaceous-illitic packets (illite-dioctahedral micaceous mineral without labile beds. Hyddromica dioctahedral with varying content of labile beds); M-montmorillonitic packets; $2-V$-vermiculitic packets; Ch-chlo-
rite packets. 
fragments have varying degrees of roundness. The fine sand and silt fractions contain varying amounts of brown vesicular and achromatic volcanic glass fragments. The heavy mineral fraction is often enriched in hornblende (metamorphic), and monoclinic pyroxene. Also observed were: rose-colored garnet, kyanite, and zircon. Siliceous sponge spicules are nearly absent, as are diatom tests. However, foraminiferal tests (planktonic) have scattered occurrences.

\section{Series 2 (31.5-67.5 m; Samples 2019-2033)}

Characteristic of this series are: an abundance of authigenic glauconite, fragments of achromatic, transparent and white, opaque acid volcanic glasses, diatom tests, and sponge spicules. Noteworthy is the presence of fragments (pellets?) of a pale green montmorillonite clay, as well as diffuse montmorillonite areas (of the same type as in fragments). This montmorillonite, obviously, has developed from volcanic ash.

The upper part of this series (Sample 2019) is enriched in virtoclastic material and is classified as a tuffite. Large amounts of other volcanic material are also present: fragments of green common hornblende, brown biotite plates, and grains of monoclinic pyroxene. The content of glauconite and siliceous skeletons is less than in the lower portion of the series.

The lower part of the series (Samples 2020-2022) contains clay-sand-silt with abundant glauconite and large areas of newly formed montmorillonite. Glauconite grains are fresh or slightly oxidized at the surface (Table 2, Sample 2021). They are larger than most terrigenous clastic particles and have an isometric shape with deep, open "septarian" fissures. Silt-size and finer grains of quartz, feldspars, quartzites, plates of colorless and green micas and glauconite are present within a matrix of light green montmorillonite. Larger fragments of vesicular glasses are partly replaced by glauconite. Glauconite is also observed in channels of some sponge spicules.

Predominant in the montmorillonite association is a Na-Ca-montmoriilonite of an aluminum-iron type, with a content from $60 \%$ to $85 \%$ in the $<1 \mu \mathrm{m}$ and $<10 \mu \mathrm{m}$ fractions. Structurally, the montmorillonite is strongly associated with glauconite. The mica component (to $30 \%$ ) is either aluminium illite, or hydromica with $10 \%$ to $20 \%$ expandable layers. Defective chlorite and kaolinite are present as minor admixtures (Table 1).

\section{Series 3 (67.5-120.5 m; Samples 2034-2060)}

The series is composed of predominantly silty-clayey deposits which are gray because of scattered organic matter. The deposits contain abundant sponge spicules and diatom tests, as well as a variable amount of pyroclastic material, including fragments of predominantly basic volcanic glasses, and fragments of hornblende and monoclinic pyroxene crystals. The series is divided into two subseries.

\section{Subseries 3-1 (67-5-84.0 m, Samples 2034-2042)}

Clay siltstones with admixture of sand-size particles of quartz, feldspars, basalt fragments, siliceous rocks,
TABLE 2

Chemical Composition of Samples $(<10 \mu \mathrm{m})$ from Site 346

\begin{tabular}{|c|c|c|c|c|c|}
\hline \multirow[b]{2}{*}{ Oxides } & \multicolumn{2}{|c|}{ Series 1} & \multirow{2}{*}{$\begin{array}{c}\text { Series } 2 \\
2021\end{array}$} & \multicolumn{2}{|c|}{ Series 3} \\
\hline & 2015 & 2017 & & 2036 & 2040 \\
\hline $\mathrm{SiO}_{2}$ & 54.99 & 56.11 & 55.93 & 54.60 & 54.65 \\
\hline $\mathrm{TiO}_{2}$ & 1.29 & 1.13 & 0.92 & 1.01 & 1.13 \\
\hline $\mathrm{Al}_{2} \mathrm{O}_{3}$ & 17.95 & 17.28 & 14.75 & 18.34 & 17.58 \\
\hline $\mathrm{Fe}_{2} \mathrm{O}_{3}$ & 7.61 & 7.28 & 8.40 & 6.21 & 5.91 \\
\hline $\mathrm{FeO}$ & 0.49 & 0.54 & 0.83 & 0.94 & 1.46 \\
\hline $\mathrm{CaO}$ & 1.56 & 1.59 & 1.01 & 0.71 & 0.74 \\
\hline $\mathrm{MgO}$ & 2.43 & 2.16 & 2.43 & 1.91 & 2.12 \\
\hline $\mathrm{MnO}$ & 0.07 & 0.06 & 0.02 & 0.03 & 0.03 \\
\hline $\mathrm{Na}_{2} \mathrm{O}$ & 1.61 & 1.48 & 0.31 & 0.62 & 0.72 \\
\hline $\mathrm{K}_{2} \mathrm{O}$ & 3.14 & 2.98 & 1.11 & 2.62 & 2.40 \\
\hline $\mathrm{H}_{2} \mathrm{O}^{+}$ & 4.21 & 5.09 & 7.29 & 6.70 & 7.23 \\
\hline $\mathrm{H}_{2} \mathrm{O}-$ & 3.63 & 3.21 & 5.86 & 4.81 & 4.73 \\
\hline $\mathrm{CO}_{2}$ & 0.17 & 0.20 & - & 0.49 & - \\
\hline $\mathrm{C}$ & 0.39 & 0.53 & 0.58 & 0.44 & 1.26 \\
\hline $\mathrm{P}_{2} \mathrm{O}_{5}$ & 0.06 & 0.06 & 0.08 & 0.09 & 0.02 \\
\hline$\Sigma$ & 99.61 & 99.70 & 99.56 & 99.52 & 99.98 \\
\hline $\mathrm{SiO}_{2} \mathrm{qw}$ & 11.76 & 14.52 & - & - & - \\
\hline $\mathrm{SiO}_{2}$ & - & 1.62 & - & - & - \\
\hline
\end{tabular}

Note: Sample $2015=(4-1,129-131 \mathrm{~cm})$, silty clay; Sample $2021=(5-2,40-42 \mathrm{~cm})$, clay with glauconite; Sample $2036=(9-1,80-82 \mathrm{~cm})$, silty clay with volcanic ash; Sample 2040 $=(9-5,29-31 \mathrm{~cm})$, clayey silt with biotite.

and mica flakes. Subordinate layers consist of finegrained polymictic sand, with rare limestone fragments. Single glauconite grains and basic or, less frequently, acid volcanic glass fragments are also present.

The clay fraction is characterized by a montmorillonite-chlorite association with illite. The montmorillonite has a $\mathrm{Ca}, \mathrm{Mg}$ absorbed complex of exchange cations. Trioctahedral chlorite constitutes a substantial component, and the mica (illite) is aluminum-containing, dioctahedral without expandable layers (Table 1).

\section{Subseries 3-2 (84.0-120.5 m, Samples 2043-2060)}

The subseries consists of dark gray clays permeated by humus, carbonaceous detritus, and an admixture of silty quartz particles. Also present, are feldspars particles, achromatic and green micas, and sponge spicules. The clay is bioturbated.

\section{Clay Mineralogy}

Subseries 3-2 is characterized by a montmorillonitehydromica association. Na-montmorillonite accounts for up to $50 \%-60 \%$, the hydromica (to $20 \%-30 \%$ ) is dioctahedral (up to $20 \%$ expandable layers), and there is a small admixture of defective chlorite and kaolinite. Unordered mixed-layer hydromica-montmorillonitetype minerals are also present.

Series 4 (Sections 14-2 to 20-2, 120.5-180.0 m; Eocene)

The series consists of massive sandy siltstones, containing scattered gravel-size material of rounded 
quartz, feldspars, and other fragments. Stratification is absent. The color is a monotonous, dark/light greenish-gray of a darker or lighter shades. All layers are noticeably bioturbated, and the internal nuclei of the burrow passages are characterized by a lighter coloring. Less frequently, they have been transformed into replicas of fine-grained pyrite aggregates.

Graded interlayers are present in the lower part of the series. The basal portions are sandstones (often calcareous) or siltstones, and the upper portion, siltstones or sorted clays. These interlayers may be as thick as $30 \mathrm{~cm}$. The lower half of the series also contains rare and thin layers of volcanic ash.

The most dominant rocks in the series are sandy siltstones composed of terrigenous material. Included are (in order of abundance): quartz, feldspars, fragments of quartzite-like sandstones and siltstones, large fragments of a siliceous-opal substance (biogenic?), fragments of decayed rocks of the femic group, rounded shreds of brown and light volcanic glasses, hydrated and deformed biotite/muscovite plates, fragments of basaltic hornblende crystals, and shreds and sometimes rounded fragments of glauconite-chlorite or ture glauconite globules.

Many quartz grains contain relics of regeneration rims inherited from preexisting sedimentary series. Based on previous work (Simanovich, 1975), it is possible to categorize the clastic quartz grains: quartz of metamorphic complexes (60\%-75\%), quartz of ancient granitoids (15\%-25\%), quartz of young granitoids $(10 \%)$, and vein quartz (10\%). All together, the clastic quartz represents a typical "shield" association. A wide spectrum of plagioclases from albite (single grains) to andesite-labradorite, and single grains of potassium feldspar were observed.

The clay matrix consists of a polycomponent mixture of minerals, predominantly the products of biotite transformation. These include a montmorillonite mineral formed by a series of mixed-layer montmorillonite-verticulite layers. There is a broad plateau on the diffraction patterns of untreated samples in the region with $d(001)$ equal to $10-14 \AA$, and a continuous indented peak in the 14.4-18 $\AA$ region on the diffraction pattern of saturated samples. The "biotite" nature of the main illite-like hydromica component is established by the presence of relict chlorite layers, which are products of the alteration of trioctahedral hydromicas. The presence of these layers is recorded on diffraction patterns of preheated samples by a constant assymetry of the basal peak with a better developed wing to the side of small angles. Other clay minerals include a Fe-chlorite, with a defective brucite structure. This is indicated by a lowered reflection with $d=1.3$ $13.7 \AA$ on diffraction patterns of preheated samples. There is also a small, but constant admixture of kaolinite.

All siltstones are enriched in carbonaceous organics (to $10 \%$ )(Table 3). Pyrite microconcretion and sometimes pyrrhotite develop after organic substances. The former are characterized, quite often, by irregular dendroid-ramified shape, obviously inherited from the configuration of larger dendrite material; the latter are represented by an aggregate of isometric-plate units, responsive to a magnetic field.

The continental-platform nature of clastic material is illustrated quite graphically by the chemical analyses of

TABLE 3

Chemical Composition of Samples From Site 346

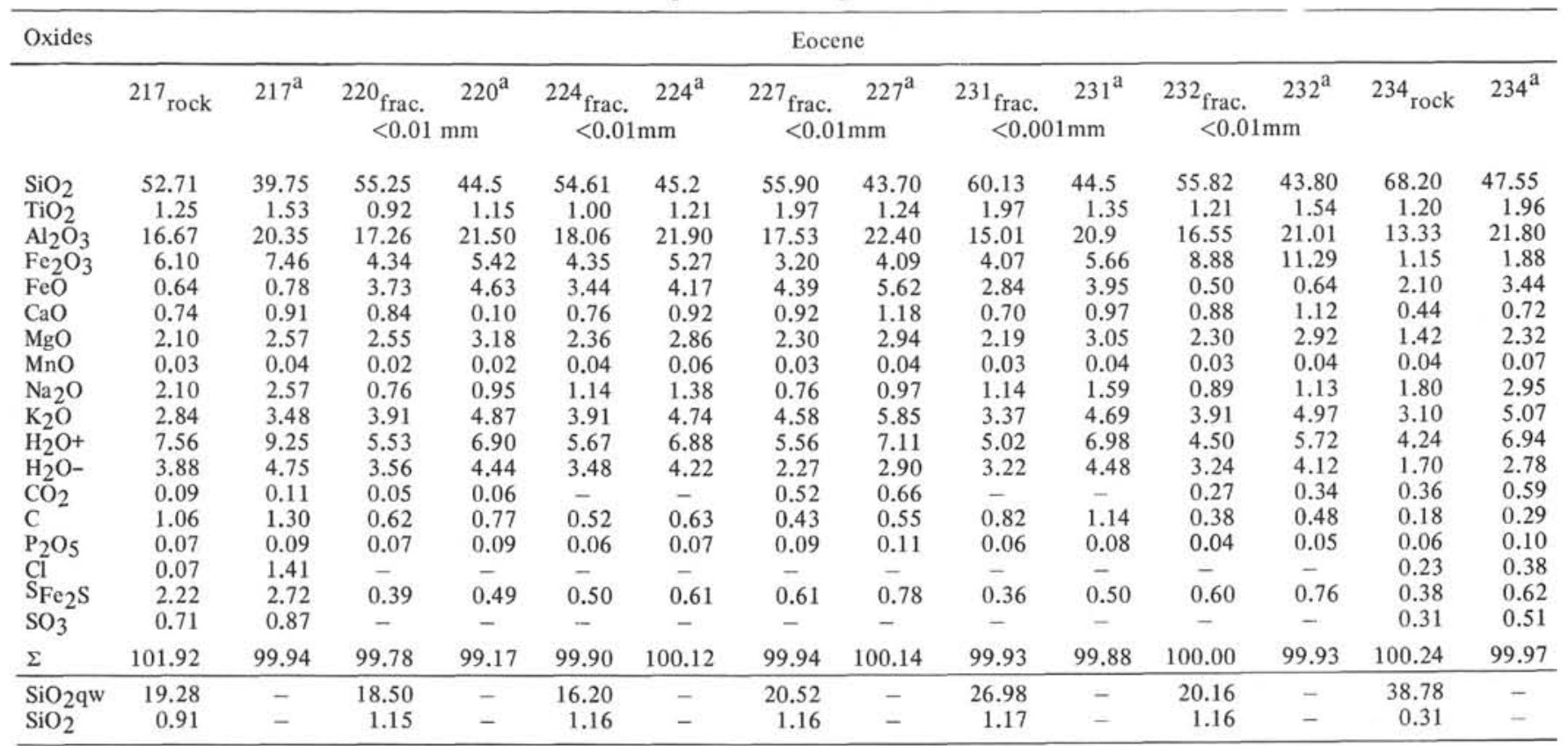

Note: Sample $217=(14-1,19-21 \mathrm{~cm})$, terrigenous clay; Sample $220=(14-5,27-29 \mathrm{~cm})$, clayey siltstone; Sample 224 $=(15-5,75-77 \mathrm{~cm})$, poorly graded siltstone; Sample $227=(17-1,75-77 \mathrm{~cm})$, poorly graded siltstone; Sample $231=(18-2,93-94 \mathrm{~cm})$, poorly graded siltstone; Sample $232=$ $(18-3,118-120 \mathrm{~cm})$, poorly graded siltstone; Sample $234=(19-2,58-60 \mathrm{~cm})$, poorly graded siltstone. 
bulk samples (Table 3, Samples 217 and 234), and the clay fraction $(<0.01 \mathrm{~mm}$ ) (Samples 220-232). In both analyses, an increased content of aluminum oxides $(21.5 \%-22.4 \%)$, ferrous oxides $(3.4 \%-4.4 \%)$, and potassium oxides $(3.3 \%-4.6 \%)$ is noted. The analysis clearly shows that the composition of the $<0.001 \mathrm{~mm}$ fraction is very similar to the chemical composition of decayed biotite-phologopite micas. Here, magnesium oxides had been washed out during alteration, ferrous oxide was partly oxidized, and the aluminum oxide content (associated with kaolinite formation) was increased somewhat. This chemical makeup of the clay fraction, so unusual for oceanic sediments, is certainly associated with characteristics of primary finedispersed clay and clastic material supplied from the continent, consisting largely of products of secondary transformation of trioctahedral micas. However a part of biotite could have been eroded from alkaline basalts enriched in biotite, such as found in Tertiary lavas of Jan-Mayen Ridge (Flower, 1969).

In all sandstone-clay siltstones of the series, especially in the lower portions, a secondary texture is observed, associated with a diagenetic dissolution of terrigenous fragments. This generally occurs perpendicular to the bedding. The most noticeable dissolution of the grains took place at the contact with the layers of clay material. Here, initially isometric grains of feldspar and quartz, first developed an "indented" pattern, and then gradually became thinner and thinner to turn in some cases into wedge-like units elongated and stretched along the direction of layers. The regeneration shells, sometimes observed on clastic quartz grains, were preserved in the process as small adjunts at the sides, while being completely dissolved in the directions coinciding with the planes of layers.

The dissolution of quartz and other clastic grains seems to be associated with the weight of overlying layers, and a favorable alkaline medium developed as a result of biotite alteration. Similar features have been observed in various continental complexes. In particular, the process was described as "gravitational corrosion" or "indented" dissolution which took place during diagenesis-epigenesis of biotite-enriched terrigenous rocks (Kopeliovich, 1965; Shutov, 1960).

The study of the sandy siltstones has indicated that dissolved substances (primarily $\mathrm{SiO}_{2}$ ) underwent lateral removal, and were redistributed along the corresponding layers. It was transported from places where the process took place and fixed as an opalic or opalsiliceous cement welding adjacent grains and fragments in the most permeable areas. This gave rise to insular lenses of cemented portions among sandy layers. The local secondary cementation of rocks by amorphous $\mathrm{SiO}_{2}$ apparently accounts for the strong lithification of the series.

\section{PRINCIPAL RESULTS AND CONCLUSIONS}

Three sediment series corresponding to the major subdivisions established by the shipboard party have been identified. The study has made it possible to distinguish subseries, with specific petrographic and mineralogical descriptions. The relevant data are in (Figure 1 and Tables 1-3.

1) Pleistocene sediments of the first series from 0 to 31.5 meters are represented by pelitomorphous, calcareous, sometimes tuffaceous clays. They contain sand-silty polymictic ice-rafted material. Included are fragments of biotites-amphibole schists. Accordingly, the composition of the clay fraction is polycomponent with an abundance of terrigenous hydromicas (to 60\%$70 \%$ ) (including muscovite and biotite), with chlorite $(20 \%-30 \%)$. The chlorite has a genetic relation with biotite, which is also true of mixed-layer vermiculitemontmorillonite minerals. The biotite is green and petrographic study reveals all stages of decay. There can be doubt of a continental origin, as biotite with a pyroclastic origin is bright brown and has a fresher appearance.

2) Glauconite is associated with the Series 2 deposits, which consists of light colored sand-silt-clays. The glauconite is present as globules, and authigenic grains with shrinkage fissures. It is present within montmorillonite clays, with an abundance of sponge spicules and an admixture of acidic ash matter. X-ray data show the glauconite to be a continuous mixedlayer micamontmorillonite mineral series with an increasing amount of mica layers up to true glauconite. In the diffraction patterns, the mixed-layer glauconite-like minerals have a diffuse maximum in the region of $d=$ 17.5 to $9.8 \AA$. True glauconite has crystal lattice parameters: $a=5.22 ; b=9.08 ; c=10.30 \AA ; B=100^{\circ}$ and a polymorphous modification $1 \mathrm{Md}$ with an admixture of $1 \mathrm{M}$.

3) The study of Series 4 has indicated that clastic material forming the uniform poorly sorted siltstones is represented by a feldspar-quartz association redeposited from the platform, in combination with abundant fragments of quartz and biotites.

The clay fraction consists almost entirely of clastic products from the alteration of trioctahedral micas in whose composition the transitional chloritic phase is also clearly observed. The transformation products of biotite-phlogopite micas are for the most part associated with the alteration and redeposition of ancient quartz-biotite schists and gneisses from Greenland. However, a possible volcaniclastic or volcanogenic origin for a part of biotite (phlogopite) cannot be ruled out.

A terrigenous origin for biotite in Series 4 is suggested by the absence of any considerable amount of volcanic components. This is in spite of the site being located on the Jan-Mayen Ridge. This confirms the conclusion of Leg 38 for a continental crust in this area and a genetic connection of the Jan-Mayen Ridge with Greenland during the Eocene-Oligocene.

4) The abundance of quartz and siliceous-opal clastics with the alkaline nature of clay material, and the action of the weight from overlying rocks has promoted the development of processes of diagenetic dissolution of clastic grains, and secondary redistribution of amorphous $\mathrm{SiO}_{2}$. This is, perhaps, a cause for the lithification of the Series 4 rocks. 


\section{REFERENCES}

Flower, M.F., 1969. Phlogopites from Jan Mayen Islands (North Atlantic): Earth Planet. Sci. Lett., v. 6, p. 461-466.

Kopeliovich, A.V., 1965. Epigenesis of old strata in the southwest of the Russian platform: Trudy GIN Akad. Nauk SSSR, v. 121.
Shutov, V.D., 1960. Epigenetic zonation of Paleozoic and Riphean deposits of the Pachelma depression: MOIP Bull., Ser. Geol., v. XXXV (6).

Simanovich, I.M., 1975. Quartz of arenaceous rocks (genetic types and postsedimentary transformations): Synopsis of thesis $M$. 